\title{
Aplikasi Prinsip Ergonomi pada perancangan Alat Perajang Bahan Baku Keripik yang Multiguna
}

\author{
Syafiatul Ummah dan I Nyoman Sutantra \\ Departemen Teknik Mesin, Fakultas Teknologi Industri, Institut Teknologi Sepuluh Nopember (ITS) \\ e-mail:tantra@me.its.ac.id
}

\begin{abstract}
Abstrak- Alat perajang bahan baku keripik yang beredar di masyarakat Indonesia sudah bermacam-macam bentuknya. S alah satunya perajang konvensional dan perajang keripik semiotomatis. Alat tersebut juga memiliki kapasitas yang kecil dan kurang nyaman saat yang digunakan. Perancangan alat perajang bahan baku keripik ini membutuhkan 2 tahap pengerjaan, yaitu perancangan serta perhitungan transmisi dan perancangan serta perhitungan rangka alat perajang bahan baku keripik. Perancangan serta perhitungan transmisi merupakan tahap pertama yang dimulai dengan mencari nilai gaya potong bahan baku, tegangan geser, torsi, daya motor yang akhirnya didapatkan rasio transmisi yang diperlukan. Sedangkan, perancangan serta perhitungan rangka merupakan tahap kedua yang dimulai dengan mengukur (tinggi bahu tegak) TBD, (tinggi siku duduk) TSD, (tinggi plopotel) TP, dan (jarak tangan depan) JTD yang akan digunakan untuk menghitung dimensi alat perajang bahan baku keripik dan nilai kenyamanan penggunaan (ergonomis). Perancangan ini menghasilkan alat perajang bahan baku keripik yang ergonomis dengan ukuran $72 \times 60 \times 99.9 \mathrm{~cm}$ dan menggunakan material ST 37. Alat perajang tersebut mampu merajang sebanyak $65 \mathrm{~kg} / \mathrm{jam}$ dengan putaran sebesar 70 RPM dibantu dengan 2 pisau pada 1 piringan pisau. Piringan pisau memiliki diameter sebesar $30 \mathrm{~cm}$ dengan tebal $1.5 \mathrm{~cm}$ yang memiliki 2 lubang dengan ukuran $10 \times 3 \mathrm{~cm}$ dan terbuat dari stainless steel. Lubang pada piringan digunakan untuk tempat pisau potong, pisau potong memiliki ukuran $10 \times 2 \times 0.2 \mathrm{~cm}$ berbahan dasar baja steel. Alat perajang tersebut memiliki 4 ketebalan yang berubah rubah untuk memenuhi kebutuhan perajangan pada bahan yang berbeda-beda.
\end{abstract}

Kata Kunci-Alat Perajang, Ergonomis, Multiguna.

\section{PENDAHULUAN}

$\mathrm{P}$ ERKEMBANGAN teknologi dibidang pertanian sangat diperlukan. Salah satu alat pertanian yang membutuhkan penelitian lanjutan adalah alat perajang bahan baku keripik. Alat tersebut telah tersedia dalam macam-macam bentuk. Diantaranya alat perajang konvensional berbentuk kotak yang terbuat dari kayu jati dengan pisau ditengah-tengahnya dan memiliki kapasitas $8 \mathrm{~kg} / \mathrm{jam}$. Kemudian alat perajang semimanual yang berbentuk lingkaran dengan pisau disekelilingnya dan memiliki kapasitas $22 \mathrm{~kg} / \mathrm{jam}$. Alat yang sudah ada juga hanya digunakan untuk merajang singkong saja.

Ubi kayu dan ubi jalar berada pada posisi kedua dan ketiga sebagaibahan makanan pokok yang paling banyak dikonsumsi setelah nasi [1]. Umbi-umbian sendiri mengandung karbohidrat yang tinggi sehingga cocok untuk dijadikan makanan pokok pengganti nasi. selain itu sukun juga banyak mengandung vitamin lainnya, seperti kalori, protein, dan lemak.

Selain kapasitas yang kecil, proses pemotongan dikerjakan langsung dengan posisiduduk diatas lantai. Proses pemotongan dengan keadaan tersebut menyebabkan posisi kerja yang tidak nyaman bagi pekerja karena dilakukan dengan posisipunggung yang membungkuk, posisi kepala yang selalu tertunduk dan kaki yang selalu tertekuk. Kondisi kerja yang demikian dapat dipastikan pekerja mengalami kelelahan dan rasa sakit pada posisi tubuh tertentu. Dibuktikan dengan metode rapid upper limb assessment (RULA) bahwa alat tersebut membutuhkan investigasiulang dalam perancangan.

Berdasarkan masalah yang tertera diatas, dibutuhkannya perancangan baru yang mengembangkan perajang yang mampu digunakan untuk merajang berbagai bahan baku keripik yang memiliki beberapa hasil ketebalan rajang, dan nyaman digunakan untuk waktu yang lama.

\section{URAIAN PENELITIAN}

Dalam perancangan ini akan dilakukan perhitungan kebutuhan daya minimal yang dibutuhkan untuk memutar piringan pisau pada perancangan alat perajang bahan baku keripik dengan memperhitungkan nilai tegangan geser dari bahan baku yang akan dirajang. Setelah itu, dilakukan perhitungan kebutuhan jumlah pisau dan sudut pisau untuk memenuhi kapasitas yang dibutuhkan dan ketebalan hasil rajang yang diinginkan.

Perancangan ini juga membutuhkan perhitungan pada transmisi daya yang dilakukan oleh sabuk V dan pulley. Pada perancangan transmisi daya ini, memerlukan beberapa perancangan lainnya yaitu perancangan pasak, perancangan bearing, dan perancangan poros. Adapun dasar-dasar pustaka yang digunakan dapat dilihat pada penjelas an setelah ini.

\section{A. Belt dan pulley}

Sabuk atau belt adalah elemen mesin fleksibel yang dapat digunakan dengan mudah untuk mentransmisikan torsi dan putaran dari suatu komponen ke komponen lainnya. Pada perancangan sabuk $\mathrm{V}$ ini membutuhkan panjang sabuk yang dapat dicari dengan menggunakan persamaan 1 dan macammacam sabukV dapay dilihat pada gambar 1 dengan keterangan 1 terpal, 2 bagian penarik, 3 karet pembungkus, dan 4 bantal karet.. 


$$
L=2 C+\frac{\pi}{2}\left(D_{1}+D_{2}\right)+\frac{1}{4 C}\left(D_{1}-D_{2}\right)^{2}
$$

$$
\text { Dimana: } \begin{aligned}
\mathrm{L} & =\text { Panjang Sabuk }(\mathrm{mm}) \\
\mathrm{C} & =\text { Jarak Sumbu Poros }(\mathrm{mm})
\end{aligned}
$$
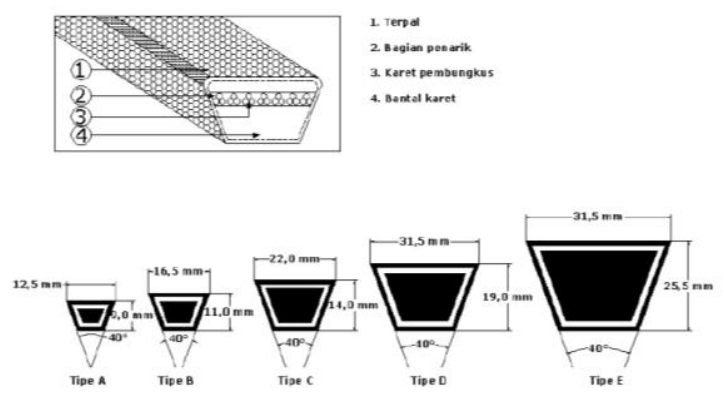

Gambar 1. Penampang sabuk V [2]

\section{B. Poros}

Poros adalah suatu bagian stasioner yang berputar, berpenampang bulat, dimana terpasang elemen-elemen seperti roda gigi, pulley, dan elemen transmisi lainnya. Poros bisa menerima beban-beban lenturan, tarikan, tekan, atau puntiran, yang bekerja sendiri-sendiri maupun gabungan. Dasar perancangan poros adalah basis " Ditortion Energy Theory". Momen bending maksimal dapat dicari dari penjumlahan momen bending secara vertikal maupun horizontal yang akan diformulasikan sebagaiberikut :

$$
M_{b}=\sqrt{\left(M_{x, H}\right)^{2}+\left(M_{x, V}\right)^{2}}
$$

Selain itu, endurance limit dapat dicari dengan menggunakan tolak ukur ultimate strength, yang dapat diformulasikan sebagai berikut:

$$
S_{e}=C_{R} \cdot C_{S} \cdot C_{f} \cdot C_{W} \cdot \frac{\grave{s}}{K_{f t}}
$$

Dimana : $S_{n}^{\prime}=0.5 S_{u}$ dan $C_{R}=1-0.08(D . M . F)$

Untuk menganalisa diameter poros yang akan digunakan sangat dipengaruhi oleh endurance limit, material dan beban kejut. Sesuai dengan teori kegagalan fatique Tresca dan Sondenerg, yaitu :

$$
\frac{S_{y p}}{S F} \geq \frac{32}{\pi \cdot d^{3}} \sqrt{K_{s b}\left(\frac{S_{y p}}{S_{e}} \cdot M_{r}\right)^{2}+\frac{3}{4} K_{s t}\left(T_{m}\right)^{2}}
$$

\section{Pasak}

Pasak merupakan suatu elemen mesin yang dipakai untuk menetapkan bagian-bagian mesin seperti roda gigi, sprocket, katrol, kopling, atau komponen-komponen sejenisnya pada poros. Pasak berfungsi untuk mencegah adanya putaran relatif antara poros dari mesin dengan peralatan mesin yang lain. Gambar 2 merupakan ilustrasi dari pasak:
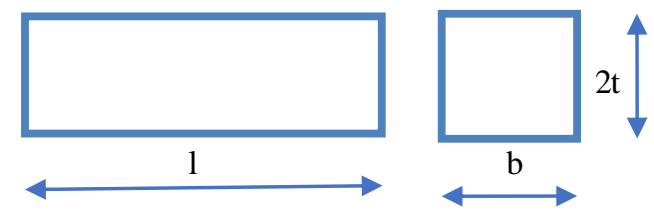

Gambar 2. Ilustrasi Gaya-gaya pada Pasak

Syarat keamanan pasak terhadap tegangan geser $\tau \leq \frac{S_{S y}}{S F}$ dimana $\mathrm{S}_{\text {sy }}$ bernilai sebesar 0.58Sy dan SF sebesar 2.5 untuk bahan yang tidak memiliki beban kejut. Sehingga keamanan pasak dapat diformulasikan sebagai berikut :

$$
\frac{F t}{b . l} \leq \frac{S_{s y}}{S F}
$$

Sedangkan syarat keamanan pasak terhadap tegangan kompresi $\leq \frac{S_{y}}{S F}$. sehingga keamanan pasak dapat di formulasikan sebagaiberikut :

$$
\frac{F t}{t . l} \leq \frac{S_{y}}{S F}
$$

\section{Bantalan}

Bantalan berfungsi sebagai penghubung antara elemen gerak dengan body diam, dengan media ini tentuny a diharapkan daya yang ditransferkan dari input akan dapat dipindahkan ke elemen mesin yang lain dengan loses energy seminimal mungkin akibat gesekan antar elemen. Beban-beban yang berpengaruh pada bantalan terdapat pada tumpuan, yang dapat diformulasikan seperti berikut :

$$
P=x \cdot V \cdot F r+y \cdot F a
$$

Dimana nilai $\mathrm{Fr}$ dapat dicari dari persamaan $\mathrm{Fr}=$ $\sqrt{{F_{H}}^{2}+{F_{V}}^{2}}$. Selain itu, umur bantalan harus diperhitungkan juga dengan menggunakan formulasi sebagaiberikut :

$$
L_{10 h}=\frac{10^{6}}{60 n}\left(\frac{C}{P}\right)^{b}
$$

\section{E. Pisau Potong}

Pisau potong yang digunakan mampu bergerak secara rotasi yang searah dengan putaran motor, dalam pembuatan pisau potong ini ada beberapa pertimbangan yang dilakukan untuk memotong material lunak. Sudut pisau yang dibutuhkan sesuai dengan ketebalan hasil potong yang diinginkan [3], dapat disederhanakan melalui rumus berikut :

$$
v_{\text {makx }}=\varphi \cdot b^{1,23} \cdot \alpha^{-1,67}
$$

Dimana :

$\mathrm{v}=$ kecepatan potong $(\mathrm{m} / \mathrm{s}) \mathrm{b}=$ ketebalan hasil potong $(\mathrm{m})$

$\alpha=$ sudut pisau potong $\left({ }^{0}\right) \varphi=$ kekenyalan material $\left(\mathrm{N} / \mathrm{m}^{2} . \mathrm{s}\right)$

untuk mencari banyaknya pisau potong dapat

menggunakan perumusan sebagaiberikut:

$$
n=\frac{Q}{m \cdot z}
$$

Dimana :

$\mathrm{n}=$ putaran pada puli 1 (RPM)

$\mathrm{Z}=$ jumlah pisau potong

$\mathrm{Q}=$ kapasitan yang diinginkan $\left(\frac{\mathrm{Kg}}{\mathrm{jam}}\right)$

$\mathrm{m}=$ massa hasil potong $(\mathrm{Kg})$

\section{F. Rangka}

Rangka merupakan salah satu bagian terpenting dari setiap mesin yang mampi menerima berbagai macam beban, rangka bisa menerima beban lenturan, tarikan, tekan atau puntiran, yang bekerja sendiri-sendiri atau berupa gabungan antara yang satu dengan yang lainnya [4]. Hal-hal yang perlu diketahui dalam perhitungan kekuatan rangka, sebagai berikut:

Perhitungan reaksi tumpuan dan momen penampang dapat dicari menggunakan persamaan sebagai berikut :

$$
\begin{aligned}
& R_{a}=\frac{q b}{(a+b)} \\
& \sum M_{A}=0 .+U \\
& q \cdot a-R_{b} \cdot(a+b)+M=0
\end{aligned}
$$

Keterangan : 
$\mathrm{R}_{\mathrm{b}}=$ Reaksi tumpuan $(\mathrm{N}) \quad \mathrm{q}=$ Beban / Gaya $(\mathrm{N})$ $\mathrm{a}=\operatorname{Jarak}(\mathrm{m})$

selanjutnya, dilakukan pemilihan profil rangka dan dihitung nilai momen inersianya dengan menggunakan titik tengah dari profil rangka tersebut. Perumusan dapat dilihat sebagaiberikut:

$$
\begin{aligned}
& y=\frac{\sum\left(A_{1} \cdot Y_{1}\right)-\left(A_{2} \cdot Y_{2}\right)}{\left(A_{1}-A_{2}\right)} \\
& I_{1}=I_{0}+\left(A_{1} \cdot Y_{1}^{2}\right) \\
& I_{x}=I_{1}-I_{2}
\end{aligned}
$$

Dimana :

$$
\begin{array}{lll}
\mathrm{A}_{1}=\text { Luasan Besar }\left(\mathrm{m}^{2}\right) & \mathrm{A}_{2}=\text { Luasan Kecil }\left(\mathrm{m}^{2}\right) \\
\mathrm{Y}_{1}=\text { Panjang Besar }(\mathrm{m}) & \mathrm{Y}_{2}=\text { Panjang Kecil }(\mathrm{m}) \\
\mathrm{I}_{1}=\text { Momen Inersia dicari } & \mathrm{I}_{0}=\text { Momen Inersia awal }
\end{array}
$$

Selanjutnya, dicari nilai tegangan geser minimum untuk rangka yang dibutuhkan dengan perumusan sebagaiberikkut :

$$
\tau=\frac{T \cdot r}{I_{x}}
$$

Keterangan :

$\tau=$ Tegangan geser $\quad T=$ Momen punter

$\mathrm{r}=$ Jari-jari silinder $\quad I=$ Momen Inersia Batang

\section{G. Rapid Upper Limb Assessment (RULA)}

Rapid Upper Limb Assessment (RULA) adalah suatu metode penilaian terhadap bagian tubuh dan otot seorang saat beraktivitaa,yang diukur dengan tingkat risiko cedera (degree og unjury risk). RULA banyak diterapkan untuk meng evaluasi ergonomic suatu produk. Langkah-langkah RULA ada tiga (3) tahapan. Seperti yang dipaparkan pada tabel 1.

Tabel 1.

Tahapan Aplikasi Metode RULA [5]

\begin{tabular}{cl}
\hline \hline Langkah & Uraian \\
\hline 1 & Penilaian postur kerja tubuh \\
2 & Penilaian kelompok postur kerja tubuh \\
3 & Penjumlahan nilai total \\
\hline \hline
\end{tabular}

\section{ANALISIS DAN PERHITUNGAN}

\section{A. Hasil dan Data Percobaan Bahan Baku Keripik}

Pengujian bahan baku keripik dilakukan untuk mencari tegangan geser yang dibutuhkan untuk merancang pis au potong dan daya minimal yang dibutuhkan untuk perajangan. Berdasarkan gambar 3 dapat disimpulkan bahwa nilai terbesar tegangan pada sukun dan nilai terendah pada ketela pohon. Sedangkan waktu penyimpanan ketela pohon selama 4 hari, ketela rambat selama 3 hari, dan sukun selama 2 hari.

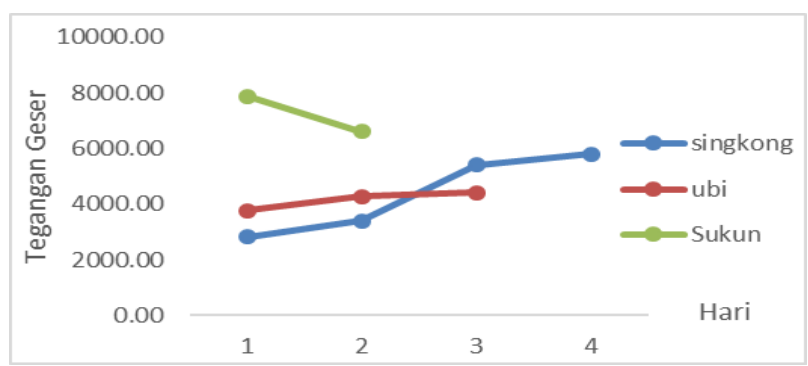

Gambar 3 Grafik Besar Nilai Tegangan Geser Terhadap Hari pengambilan

setelah diputuskan data yang akan digunakan dalam perhitungan,dibutuhkan dilakukan pengecekan berkelanjutan mengenai data tersebut. Pengecekan-pengecekan yang perlu dilakukan diantaranya keseragaman (tabel 2) data serta toleransi yang diperbolehkan (tabel 3).

Tabel 2.

Hasil Keseragaman Data Pengujian Bahan Baku dengan tingkat keyakinan 95\% (Tegangan Geser)

\begin{tabular}{|l|l|c|c|c|c|l|}
\hline No & $\begin{array}{l}\text { Deskripsi } \\
\text { Data }\end{array}$ & $\bar{N}\left(\frac{N}{\mathrm{~m}^{2}}\right)$ & $\sigma$ & BTA & BTB & Kesimpulan \\
\hline 1 & $\begin{array}{l}\text { Ketela } \\
\text { Pohon }\end{array}$ & 3396.06 & 163.8 & 3723.66 & 3068.46 & $\begin{array}{l}\text { Data } \\
\text { seragam }\end{array}$ \\
\hline 2 & $\begin{array}{l}\text { Ketela } \\
\text { Rambat }\end{array}$ & 4273.53 & 329.3 & 4932.13 & 3614.93 & $\begin{array}{l}\text { Data } \\
\text { seragam }\end{array}$ \\
\hline 3 & Sukun & 6605.90 & 1364 & 9333.9 & 3877.9 & $\begin{array}{l}\text { Data } \\
\text { seragam }\end{array}$ \\
\hline
\end{tabular}

Tabel 3.

Hasil Perhitungan Persentil nilai keyakinan 90\%

\begin{tabular}{llll}
\hline \hline No & Deskripsi data & P-5 & P-95 \\
\hline 1 & Ketela Pohon & 3127 & 3665 \\
2 & Ketela Rambat & 3730 & 4814 \\
3 & Sukun & 4362 & 8850 \\
\hline \hline
\end{tabular}

B. Perhitungan Kebutuhan Pisau dan Sudut Pisau

Perhitungan pisau sangat erat sekali kaitannya dengan pemenuhan kapasitas, dimana kapasitas $(\mathrm{Q})$ yang diinginkan sebesar $65 \mathrm{~kg} / \mathrm{jam}$ dengan kecepatan putaran piringan (n2) sebesar 70RPM. Massa satu kali perajangan (m) dapat dicari dengan cara pengambilan secara acak bahan baku yang telah dirajang sebesar 350 gram dan jumlah potongan yang dirajang sebanyak 40 buah.

$$
\begin{aligned}
m & =\frac{350 \mathrm{gram}}{40} \\
& =8.75 \mathrm{gram}=0.00875 \mathrm{~kg} \\
Z & =\frac{65 \frac{\mathrm{kg}}{\mathrm{jam}} \cdot \frac{1 \mathrm{jam}}{60 \mathrm{menit}}}{0.00875 \mathrm{~kg} .70 \mathrm{RPM}}
\end{aligned}
$$

\begin{tabular}{|c|c|c|c|c|}
\hline $\begin{array}{c}\text { Tebal } \\
(\mathrm{m})\end{array}$ & $\varphi\left(\frac{k g}{m \cdot s^{3}}\right)$ & $v\left(\frac{m}{s}\right)$ & $\alpha\left(^{0}\right)$ & $\overline{\alpha \alpha+\beta\left(^{\sigma}\right)}$ \\
\hline 0.001 & 33029.5 & 1,57 & 2.4 & 47.5 \\
\hline 0.002 & & & 4.0 & 49 \\
\hline 0.003 & & & 5.4 & 50.4 \\
\hline 0.004 & & & 6.6 & 51.6 \\
\hline
\end{tabular}

Berdasarkan perhitungan didapatkan nilai massa satu kali rajang sebesar $0.00875 \mathrm{~kg}$ dan jumlah pisau sebanyak 2 buah. Sedangkan perhitungan sudut pisau sebanyak 4 kali, denganmenggunakan persamaan 9, didapatkan hasil seperti pada tabel 4

Tabel 4.

Nilai Sudut Pisau $(\alpha)$ berdasarkan Ketebalan Bahan Baku

C. Perancangan motor, sabuk, dan katrol

Pada perancangan daya motor dibutuhkan nilai torsi yang dibutuhkan untuk satu kali perajangan.

$$
\begin{aligned}
& T=Z \times F_{2} \frac{d_{\text {blade }}}{2}=2 \times 5.19 \mathrm{~N} \times \frac{0.15 \mathrm{~m}}{2}= \\
& 0.78 \mathrm{Nm} \\
& \text { Didapatkan nilai daya dapat dicari sebagai berikut : } \\
& H p=z \times T \times \mathrm{n}_{2} \\
& H p=2 \times 0.39 \mathrm{Nm} \times 70 \mathrm{RPM}=54.6 \mathrm{Watt}=0.07 \mathrm{hp}
\end{aligned}
$$

Tabel 5 .

Data Katalog Motor Tipe IM 1001 dengan Daya sebesar $0.5 \mathrm{hp}$ 


\begin{tabular}{ccc}
\hline \hline No & Data & Ukuran \\
\hline 1 & Daya & $0.5 \mathrm{hp}, 0.37 \mathrm{~kW}$ \\
2 & Putaran & $915 \mathrm{RPM}$ \\
3 & Effesiency & $65.5 \%$ \\
4 & Torque & $3856 \mathrm{Nm}$ \\
5 & Berat & $17.5 \mathrm{~kg}$ \\
6 & Lifetime & $20000 \mathrm{hours}$ \\
7 & Panjang motor & $253 \mathrm{~mm}$ \\
8 & Tinggi / Diameter & $156 \mathrm{~mm}$ \\
9 & Diameter poros & $19 \mathrm{~mm}$ \\
10 & Pajang poros motor & $40 \mathrm{~mm}$ \\
\hline \hline
\end{tabular}

Setelah didapatkan katalog motor sepertipada tabel 5, dicari katalog untuk sabuk $\mathrm{V}$ dengan mempertimbangkan panjang sabuk V.

$L=2 C+\frac{\pi}{2}\left(D_{1}+D_{2}\right)+\frac{1}{4 C}\left(D_{1}-D_{2}\right)^{2}$

$L=2 \times 824+\frac{3.14}{2}(45+590)+\frac{1}{4 \times 824}(45-590)^{2}$

$L=2735.1 \mathrm{~mm}=107.7 \mathrm{inc}$

Setelah didapatkan panjang sabuk V, dapat disimpulkan spesifikasi sabuk V bersadarkan katalog yang digunakan seperti pada tabel 6.

Tabel 6.

Spesifikasi Motor Listrik, Sabuk V dan Katrol.

\begin{tabular}{|c|c|c|}
\hline$\overline{\mathrm{No}}$ & Data & Keterangan \\
\hline 1 & V-Belt & $\begin{array}{l}\text { Brourning Super Gripbelt are Static } \\
\text { Conducting type B } 106\end{array}$ \\
\hline 2 & Material & EPDM rubber \\
\hline 3 & Panjang v-belt & $2788.92 \mathrm{~mm}$ atau 107.7 inc. \\
\hline 4 & $\begin{array}{l}\text { Diameter pulley } \\
1\end{array}$ & SKF Pulley katalog tipe PHP 1SPZ50T \\
\hline 5 & $\begin{array}{l}\text { Diameter pulley } \\
2\end{array}$ & $\begin{array}{l}\text { SKF pulley katalog tipe PHP } \\
\text { 1SPB560TB }\end{array}$ \\
\hline 6 & Tebal pulley 1 & $22 \mathrm{~mm}$ \\
\hline 7 & Tebal pulley 2 & $51 \mathrm{~mm}$ \\
\hline 8 & Gay a Minimal & $2.7 \mathrm{~N}$ \\
\hline 9 & Gay a Maksimal & $175.6 \mathrm{~N}$ \\
\hline
\end{tabular}

\section{Perancangan dan Perhitungan Poros}

Perancangan poros dilakukan setelah mengetahui besar diameter katrol supaya dapat dihitung nilai beban serta momen momen yang diakibatkan oleh katrol tersebut. Panjang poros utama (L1) yang diinginkan sebesar $210 \mathrm{~mm}$ dan material yang digunakan merupakan ST 37 dengan nilai ultimate strength (Su) sebesar 20000 Psi dan yield strength (Syp) sebesar 17000 Psi. safety factor yang digunakan sebesar 2 karena torsi yang mengenai poros dianggap sama. Setelah ditentukan material yang digunakan, dapat dicari besar endurance limit dengan persamaan 3 .

$$
\begin{aligned}
& S_{e}=C_{R} \cdot C_{S} \cdot C_{f} \cdot C_{W} \cdot \frac{\grave{s_{n}}}{K_{f}} \\
& S_{e}=0.8976 \cdot 0.85 \cdot 0.74 .1 \cdot \frac{10000}{1.6}=3528.69 \mathrm{Psi}
\end{aligned}
$$

Setelah didapatkan nilai $\mathrm{S}_{\mathrm{e}}$, lalu dicari besar diameter poros dengan menggunakan persamaan 10 sebagai berikut :

$$
\begin{aligned}
& \frac{S_{y p}}{S F} \geq \frac{32}{\pi \cdot d^{3}} \sqrt{K_{s b}\left(\frac{S_{y p}}{S_{e}} \cdot M_{r}\right)^{2}+\frac{3}{4} K_{s t}\left(T_{m}\right)^{2}} \\
& \frac{17000}{2} \geq \frac{32}{3.14 \times d^{3}} \sqrt{1\left(\frac{17000}{3528.69} \cdot 49.16\right)^{2}+\frac{3}{4} 1(1.17)^{2}} \\
& d=0.3 \mathrm{inc}=8 \mathrm{~mm}
\end{aligned}
$$

E. Perancangan dan Perhitungan Pasak dan Bantalan

Perancangan bantalan 1 dan bantalan 2 dapat dilihat pada gambar 4 dimana letak bantalan 1 pada poros utama dengan lokasi bantalan berada di ujung sisi kanan untuk bantalan 2 dan pada jarak 180mm dari kanan.

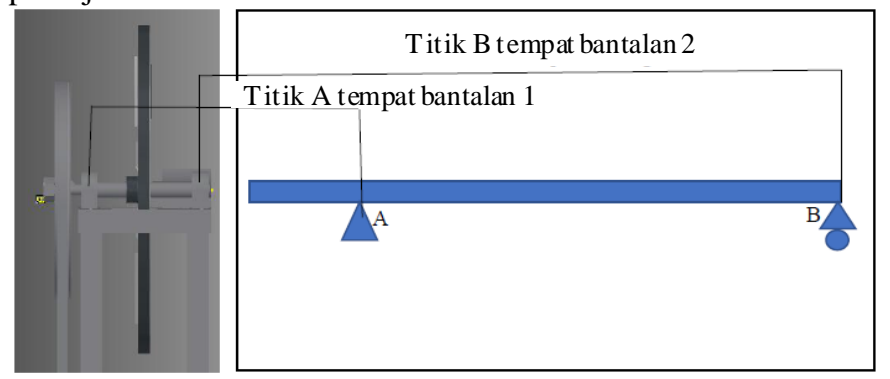

Gambar 4 Ilustrasi Letak Bantalan 1 dan Bantalan 2

Berdasarkan perhitungan poros dodapatkan diameter bantalan sebesar $25 \mathrm{~mm}$. Katalog "SKF Rolling Bearing", didapatkan tipe-tipe bearing yang diperlukan. Data lengkap

\begin{tabular}{|c|c|c|c|c|c|c|}
\hline $\begin{array}{l}\text { Bantal- } \\
\text { an ke- }\end{array}$ & $\overline{\text { Tipe }}$ & $\begin{array}{c}\mathrm{F}_{\mathrm{R}} \\
(\mathrm{Lb})\end{array}$ & $\begin{array}{c}\mathrm{C}_{\mathrm{o}} \\
(\mathrm{Lb})\end{array}$ & $\overline{C \mathrm{C}(\mathrm{Lb})}$ & $\overline{\bar{X}}$ & $\begin{array}{c}\mathrm{b} \\
(\mathrm{mm})\end{array}$ \\
\hline 1 & $\begin{array}{l}\text { Single } \\
\text { raw deep } \\
\text { groove } \\
\text { ball } \\
\text { bearing } \\
\text { Type } \\
6005\end{array}$ & 58.92 & 5845 & 26752,3 & 0.56 & 12 \\
\hline 2 & $\begin{array}{l}\text { Single } \\
\text { raw deep } \\
\text { groove } \\
\text { ball } \\
\text { bearing } \\
\text { Type } \\
6005\end{array}$ & 3.48 & 5845 & 26752,3 & 0.56 & 12 \\
\hline
\end{tabular}
dapat dilihat pada tabel 7, dengan umur bantalan dapat dilihat pada tabel 8 .

Tabel 7.

Tipe Bantalan yang Digunakan pada Perancangan

Tabel 8.

Kesimpulan Umur Bantalan dalam Putaran

\begin{tabular}{llll}
\hline \hline Bearing ke- & Gaya $(\mathrm{P})$ & $\begin{array}{c}\text { Putaran } \\
(\mathrm{n})\end{array}$ & Umur $\left(L_{10 h}\right)$ \\
\hline 1 & & 70 & 6779.14 \\
2 & 33 & 70 & 27896.37 \\
\hline \hline
\end{tabular}

Perancangan dan perhitungan pasak dilakukan untuk mengunci bagian mesin berupa katrol, bantalan, kopling pada poros. Data yang dibutuhkan dalam perancangan berupa gaya tangensial yang bekerja bagian mesin. Pasak yang digunakan pada perancangan ini berupa pasak kotak. Pasak tersebut terbuat dari material ST 37 dengan panjang pasak sama seperti tebal katrol atau bantalan. Hasil akhir dimensi pasak dapat dilihat pada tabel 9. Dimana 1 sama dengan panjang dan b sama dengan lebar.

Tabel 9.

Kesimpulan Dimensi Pasak pada Setiap Bagian dalam mm 


\begin{tabular}{clllll}
\hline \hline Pasak & $\mathrm{L}$ & $\mathrm{b}$ & $\mathrm{b}$ desain & $2 \mathrm{t}$ & 2t desain \\
\hline katrol 1 & 22 & 0.006 & 3 & 0.008 & 3 \\
katrol 2 & 51 & 0.17 & 3 & 0.2 & 3 \\
Piringan & 15 & 0.02 & 3 & 0.02 & 3 \\
bantalan & 12 & 1.03 & 3 & 1.2 & 3 \\
$\begin{array}{c}1 \\
\text { bantalan }\end{array}$ & 12 & 0.06 & 3 & 0.07 & 3 \\
2 & & & & & \\
\hline \hline
\end{tabular}

F. Perancangan dan Perhitungan Material Rangka

Perancangan rangka dibagi menjadi 2 bagian, perancangan material rangka yang menggunakan metode elemen hingga serta perancangan kenyamanan penggunakan dengan metode ergonomis.

Data tegangan geser pada rangka dapat dilihat pada tabel 10. nilai tegangan geser terbesar terdapat pada batang yang mendekati beban dari piringan. Sedangkan data gaya kritis lengkungan dapat dilihat pada tabel 11.

Tabel 10

Data Tegangan geser dan Tegangan Tarik yang Terjadi pada Rangka Alat Perajang Bahan Baku Keripik menggunakan Material ST 37 dalam Psi (Pound

\begin{tabular}{llrlll}
\multicolumn{5}{c}{ per square inc) } \\
\hline \hline Titik & \multicolumn{1}{c}{$\tau$} & $\sigma$ & $\begin{array}{l}\text { Tegang- } \\
\text { an } \\
\text { Material }\end{array}$ & $\begin{array}{l}\text { Tegang- } \\
\text { an Ijin }\end{array}$ & $\begin{array}{l}\text { Kesimpul- } \\
\text { an }\end{array}$ \\
\hline A & 1644 & & 20000 & 6576 & Aman \\
B & 96.06 & & 20000 & 384.24 & Aman \\
C & 1644 & & 20000 & 6576 & Aman \\
D & 96.06 & & 20000 & 384.24 & Aman \\
E & & 6291.68 & 20000 & 12583.36 & Aman \\
F & 870.47 & & 20000 & 3481.88 & Aman \\
G & & 6291.68 & 20000 & 12583.36 & Aman \\
H & 870.47 & & 20000 & 3481.88 & Aman \\
I & 64.23 & & 20000 & 256.9 & Aman \\
J & 1644 & & 20000 & 6576 & Aman \\
K & & 6291.68 & 20000 & 12582.4 & Aman \\
L & 64.23 & & 20000 & 256.9 & Aman \\
M & 1644 & & 20000 & 6576 & Aman \\
N & & 6291.68 & 20000 & 12582.4 & Aman \\
\hline \hline
\end{tabular}

Tabel 11.

Data Gaya yang bekerja pada Batang Rangka dengan Gaya Kritis Lengkungan

\begin{tabular}{llll}
\hline \hline Batang & Gaya $(\mathrm{N})$ & Gaya Kritis $(\mathrm{N})$ & Kesimpulan \\
\hline A-J & 131 & 135.8 & Aman \\
B-E & 7.65 & 454.2 & Aman \\
D-G & 7.65 & 454.2 & Aman \\
C-M & 131 & 135.8 & Aman \\
F-K & 138.65 & 660.9 & Aman \\
H-N & 138.65 & 660.9 & Aman \\
\hline \hline
\end{tabular}

Perhitungan ergonomis dipengaruhi oleh gerak yang dilakukan manusia dalam jangka waktu yang panjang. Perhitungan ini dibagi menjadi dua bagian, diantaranya perhitungan ergonomis grup A (paket merah) dan nilai perhitungan ergonomis grup B (paket kuning), ilustrasi dapat dilihat pada gambar 5. Perhitungan ergonomis dilakukan untuk untukgrup A dan grup B dapat dilihat dibawah ini :

Penilaian ergonomis grade A meliputi pergerakan tangan, lengan atas, lengan bawah, dan pergelangan tangan.

1. Perhitungan lengan atas.

Pergelangan tangan atas memiliki sudut 900 yang bernilai ergonomis sebesar +3
2. Perhitungan lengan bawah

Pergelangan bawah tidak memiliki pergerakan, maka nilai ergonomisnya sebesar +2

3. Pergelangan tangan

Pada pergelangan tangan, tidak mengalami pergerakan diluar 150, maka nilai ergonomisnya sebesar +1

4. Perhitungan puntiran tangan

Puntir lengan operator tidak digerakkan keluar sesuai gampang sulit, maka nilai ergonomisnya sebes ar +1

Penilaian ergonomis grup B meliputi pergerakan tangan, lengan atas, lengan bawah, dan pergelangan tangan.

1) Perhitungan leher

Operator tidak membutuhkan tekukan leher. Diperkirakan sudut leher $\leq 15^{0}$. Maka nilai ergonomisnya sebesar 1

2) Perhitungan punggung

Saat pengoperasian, diharapkan operator tidak membungkuk. Jadi punggung operator dalam posisi tegak. Nilai ergonomisnya sebesar 1

3) Perhitungan kaki

Kaki operator tidak mengalami penerimaan beban/beban seimbang. Maka nilai ergonomisnya sebesar 1

Berdasarkan penilaian grup A dan grup B dilakukan penilaian grup $\mathrm{C}$ dan grup D. Penilai ini dapat dirincikan seperti dibawah ini :

1) Mencari nilai $\mathrm{C}$

Nilai C didapatkan dari nilai postur grup A, otot, dan beban.

- Nilai posturgrup A sebesar +3

- Nilai otot yang melakukan kegiatan berulang-ulang sebanyak 4 kali lebih dalam 1 menit, maka nilai ergonomis sebesar 0

- Tidak ada beban selama pelaksanan, maka nilai ergonomis akibat beban sebesar 0

Oleh karena itu, nilai akhir penilaian $\mathrm{C}$ sebes ar +3

2) Mencari nilai $D$

Nilai D didapatkan dari nilai postur grup B, otot, dan beban.

- Nilai posturgrup B sebesar +1

- Tidak ada pergerakan aktif pada operator menyebabkan nilai ergonomis akibat otot sebesar +1

- Tidak ada beban selama pelaksanan, maka nilai ergonomis akibat beban sebesar 0

Oleh karena itu, nilai akhir penilaian D sebesar +2 


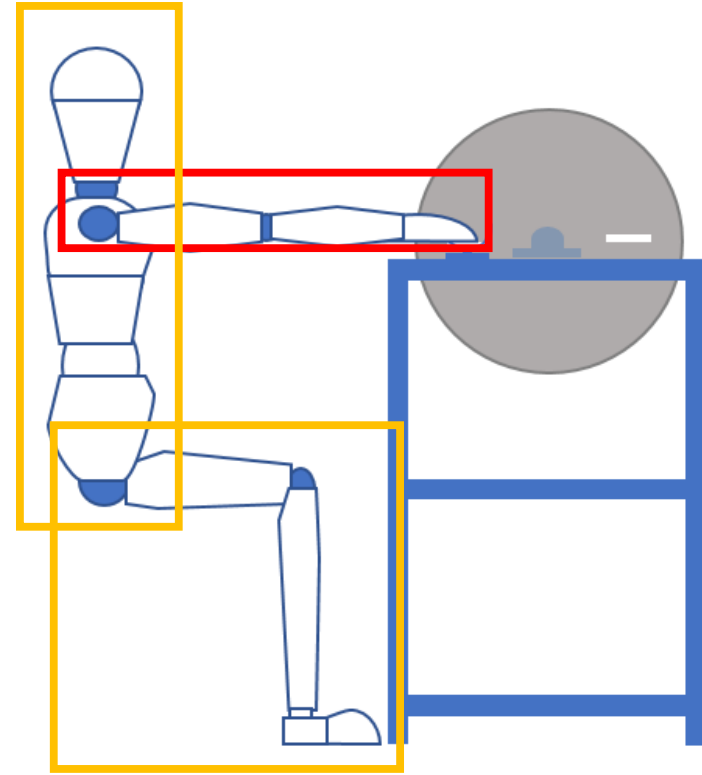

Gambar 5 Ilustrasi serta Pembagian nilai ergonomis pada grup A dan Grup B

Setelah mendapatkan nilai $\mathrm{C}$ dan $\mathrm{D}$, kita bisa memastikan nilai ergonomis suatu alat dengan menggunakan tabel 12 . berdasarkan tabel 12 disimpulkan bahwa nilai ergonomisnya sebesar 3, yang mana dapat diartikan bahwa alat tersebut sudah ergonomis.

Tabel 12.

Hasil Akhir pada Nilai ergonomis

\begin{tabular}{|c|c|c|c|c|c|c|c|c|}
\hline & \multicolumn{8}{|c|}{ Nilai D } \\
\hline \multirow{9}{*}{$\begin{array}{c}\text { Nilai } \\
\text { C }\end{array}$} & & $\bar{~} \overline{11}$ & 2 & 3 & 4 & 5 & 6 & 7 \\
\hline & 1 & 1 & 2 & 3 & 3 & 4 & 5 & 5 \\
\hline & 2 & 2 & 2 & 3 & 4 & 4 & 5 & 5 \\
\hline & 3 & 3 & 3 & 3 & 4 & 4 & $\overline{55}$ & $\overline{6}$ \\
\hline & 4 & 3 & 3 & 3 & 4 & 5 & 6 & 6 \\
\hline & 5 & 4 & 4 & 4 & 5 & 6 & 7 & 7 \\
\hline & 6 & 4 & 4 & 5 & 6 & 6 & 7 & 7 \\
\hline & 7 & 5 & 5 & 6 & 6 & 7 & 7 & 7 \\
\hline & 8 & 5 & 5 & 6 & 7 & 7 & 7 & 7 \\
\hline
\end{tabular}

G. Kelebihan dan Kekurangan dengan Alat yang sudah Ada

Pada setiap perancangan alat pasti dipertimbangkan kelebihan dan kekurangan dari alat-alat yang sudah ada. Oleh karena itu, pada subbab ini, akan ditampilkan kelebihan dan kekurangan dari alat yang akan dirancang dengan alat yang sudah ada. Kelebihan dan kekurangan tersebut dapat dilihat pada tabel 4.15

Tabel 13.

Kelebihan dan Kekurangan antara Alat yang sudah ada dengan Alat yang akan Dirancang

\begin{tabular}{|c|c|c|c|c|}
\hline No & $\overline{\text { Data }}$ & $\begin{array}{l}\text { Alat yang } \\
\text { dirancang }\end{array}$ & $\begin{array}{l}\text { Alat } \\
\text { Konvensional }\end{array}$ & $\begin{array}{l}\text { Alat Semi- } \\
\text { otomatis }\end{array}$ \\
\hline 1 & Kapasitas & $65 \mathrm{~kg} / \mathrm{jam}$ & $8 \mathrm{~kg} / \mathrm{jam}$ & $22 \mathrm{~kg} / \mathrm{jam}$ \\
\hline 2 & Tenaga & $\begin{array}{l}\text { Motor } \\
\text { listrik }\end{array}$ & Operator & Operator \\
\hline
\end{tabular}

\begin{tabular}{cllll}
3 & Kenyamanan & $\begin{array}{l}\text { Sudah } \\
\text { nyaman } \\
\text { Ketela } \\
\text { pohon, } \\
\text { ketela } \\
\text { rambat, } \\
\text { sukun } \\
\text { Bahan yang } \\
\text { dirajang }\end{array}$ & $\begin{array}{l}\text { Tidak } \\
\text { nyaman } \\
\text { Ketela pohon }\end{array}$ & $\begin{array}{l}\text { Tidak } \\
\text { ny aman } \\
\text { Ketela } \\
\text { pohon }\end{array}$ \\
5 & $\begin{array}{l}\text { Ketebalan } \\
\text { hasil potong }\end{array}$ & $\begin{array}{l}\text { ketebalan } \\
\text { Daya }\end{array}$ & 1 ketebalan & $\begin{array}{l}1 \\
\text { ketebalan } \\
6\end{array}$ \\
\hline \hline
\end{tabular}

\section{KESIMPULAN/RINGKASAN}

Pada pembuatan tugas akhir ini, hasil pengerjaan dapar disimpulkan sebagai berikut :

1. Alat perajang bahan baku keripik dapat digunakan untuk merajang 3 bahan baku yaitu ketela pohon, ketela rambat, dan sukun dengan waktu pemotongan dilakukan pada hari kedua setelah panen.

2. Alat perajang bahan baku keripik menggunakan 2 pisau potong berbahan baja steel yang ditempelkan pada piringan pisau berbahan stainless steeldengan 4 ketebalan.

3. Alat perajang bahan baku keripik menggunakan motor AC dengan kapasitas $0.5 \mathrm{Hp}$ dengan kecepatan putaran 70RPM.

4. Transmisi yang digunakan pada alat perajang bahan baku keripik merupakan pasangan $v$-belt dan pulley dengan diameter pulley $590 \mathrm{~mm}$ dan $45 \mathrm{~mm}$. V-belt $\urcorner$ yang digunakan berbahan dasar rubber EPDM.

5. Alat perajang bahan baku keripik memiliki dimensi sebesar $72 \times 60 \times 99.9 \mathrm{~cm}$ dengan pertimbangan anthopometri. Material yang digunakan dalam pembuatan rangka adalah ST 37 dengan nilai ergonomis sebesar 3 yang dapat diartikan bahwa alat tersebut sudah nyaman digunakan.

\section{UCAPAN TERIMA KASIH}

Penulis mengucapakan terima kasih kepada Bapak Prof. Ir. I Nyoman Sutantra, MSc, Ph.D. dan Bapak Moch.Solichin, S.T, M.T. yang telah membantu penulis dalam melakukan penelitian ini.

\section{DAFTAR PUSTAKA}

[1] B. P. Statistik, "Rata-rata Konsumsi Per Kapita Seminggu Beberapa Macam Bahan Makanan Penting 2011-2016," 6 Nopember 2017. [Online].

[2] k. S. Sularso, Dasar Perencanaan dan Pemilihan Elemen Mesin, Jakarta: Pradya Paramita, 2002.

[3] S. Uslianti, "Rancang Bangun Mesin Pengiris Tempe untuk Kelompok Usaha Dusun Karya I," Jurnal ELKHA, vol. 7, no. 2,2015.

[4] E. Putra, "Perbaikan Rancang Alat Pemotong Singkong dengan Mekanisme Pedal Kaki untuk Meningkatkan Produksi dengan Prinsip Ergonomi," Skripsi Jurusan Teknik Industri Fakultas Teknik Universitas Sebelas Maret, 2009.

[5] I. M. L. Batan, Desain Produk, Surabaya: Guna Widya, 2012. 